\title{
Phosphorus dynamics in a tropical forest soil restored after strip mining
}

\author{
Alister V. Spain • Mark Tibbett (D) Michael Ridd • \\ Timothy I. McLaren
}

Received: 9 November 2017 / Accepted: 26 April 2018/Published online: 23 May 2018

(C) The Author(s) 2018

\begin{abstract}
Background and aims We hypothesized that successful early ecosystem and soil development in these Pdeficient soil materials will initially depend on effective re-establishment of $\mathrm{P}$ storage and cycling through organic matter. This hypothesis was tested in a 26-year chronosequence of seven lightly fertilized, oxidic soil materials restored to eucalypt forest communities after bauxite mining.

Methods Total P (Pt) status, Hedley P fractions and partial chemical speciation $(\mathrm{NaOH}-\mathrm{EDTA}$ extraction
\end{abstract}

Responsible Editor: Daniel Menezes-Blackburn

Electronic supplementary material The online version of this article (https://doi.org/10.1007/s11104-018-3668-8) contains supplementary material, which is available to authorized users.

\section{A. V. Spain}

UWA School of Agriculture and Environment, The University of Western Australia, 35 Stirling Highway, Crawley, WA 6009, Australia

\section{Tibbett $(\bowtie)$}

Centre for Agri-environmental Research and Soil Research Centre, School of Agriculture, Policy and Development, University of Reading, Whiteknights, PO Box 237, Reading RG6 6AR, UK

e-mail: m.tibbett@ reading.ac.uk

M. Ridd

College of Science and Engineering, James Cook University,

Townsville, Qld 4811, Australia

T. I. McLaren

Department of Environmental Systems Science, ETH,

8315 Lindau, Zurich, Switzerland and analysed using solution ${ }^{31} \mathrm{P}$ NMR spectroscopy) were determined in the restored soils.

Results Concentrations of Pt and most Hedley fractions changed with restoration period, declined with depth and were strongly positively correlated with $\mathrm{C}$ and $\mathrm{N}$ concentrations. Biological $P$ dominated the Labile and Intermediate $P$ fractions while Long-term $P$ was dominantly inorganic. Organic $\mathrm{P}$ concentrations in $\mathrm{NaOH}$-EDTA extracts and their chemical natures were similar in restored and unburned native forest sites. Phosphomonoesters were the dominant class of organic P.

Conclusions Surprisingly rapid $\mathrm{P}$ accretion and fractional changes occurred over 26 years, largely in the surface soils and closely associated with organic matter status. Alkaline hydrolysis products of phosphodiesters and pyrophosphate indicated the importance of microbial $\mathrm{P}$ cycling. The important consequences for longterm ecosystem development and biological diversity require further study.

Keywords Mining · Oxisols · P-fractionation · Pspeciation $\cdot$ Pedogenesis $\cdot$ Restoration

\section{Introduction}

Phosphorus (P) is an essential element that widely conditions biological processes in all earth surface environments (Elser et al. 2007), including net primary production (Cleveland et al. 2011). In terrestrial environments, $\mathrm{P}$ availability frequently limits plant 
productivity, influences plant community composition (see, for example, Elser et al. 2007; Güsewell 2004; Knecht and Göransson 2004; Peltzer et al. 2010) and interacts with soil development processes (Crews et al. 1995; Viscarra Rossel and Bui 2016; Walker and Syers 1975).

In the highly-weathered, P-depleted, $\mathrm{Fe}$ and $\mathrm{Al}-$ enriched (Cornell and Schwertmann 2003) soils common in older tropical landscapes, the primary Pcontaining minerals, such as hydroxyapatite, are likely to have been long exhausted due to acidification (Vitousek et al. 2010; Yang et al. 2013). Much of the P present is likely to be associated with clays and the oxide and related minerals of $\mathrm{Fe}$ and $\mathrm{Al}$, or to occur in refractory organic forms (Cross and Schlesinger 1995; Yang and Post 2011). Retention of P in these soils is high (IUSS Working Group WRM 2015; Short et al. 2000, 2007) and in natural environments P supply for the support of biological activity is characteristically constrained (Lang et al. 2016). In such environments, maintenance of $\mathrm{P}$ supply occurs largely through biological recycling, desorption and diffusion from poorlyavailable forms, possibly limited aerial accession (Reed et al. 2011; Tipping et al. 2014) and, in managed environments, from fertilizer inputs.

Restoration practice at many Australian tropical mine sites aims to develop resistant and resilient ecosystems, similar to those of the surrounding unmined areas. This is only likely to be achieved where nutrient cycles are effectively re-established during early pedogenesis; as potentially the most limiting element, the initiation of P cycling is critical (Vitousek 1984). The profound disturbance associated with mining and restoration processes may lead to dilution and loss of soil $\mathrm{P}$, particularly of the relatively mobile organic $\mathrm{P}$ component (Bol et al. 2016; Frossard et al. 1989). Current knowledge of $\mathrm{P}$ dynamics in ecosystems restored on highly weathered soil materials is limited, and it is therefore of considerable theoretical and management interest to understand the changing status and fractional distribution of $\mathrm{P}$ during the early phases of pedogenesis and ecosystem development that follow restoration.

We hypothesised that early ecosystem and soil development in these P-limited oxidic materials must initially depend largely on the reestablishment of functional $\mathrm{P}$ pools associated with soil organic matter and on its biogeochemical cycling. Both processes are likely to be mediated through the activities of microorganisms and other soil organisms but additionally through complex interactions with inorganic soil materials.

Our study therefore investigated how P status, fractions and species composition changed over a 26-year chronosequence period (space-for-time substitution) of forest development in surficial and deeper soil development down to, and including, the mine floor. Specifically, we wanted to understand (i) How does total $\mathrm{P}(\mathrm{Pt})$ status change with restoration period and depth? (ii) How do the different $P$ fractions, notably the organically associated $\mathrm{P}$, develop in response to restoration period and depth, and how are these related to other properties of the developing soils? (iii) How the chemical nature of organic $\mathrm{P}$ changes in relation to restoration period in the surface soils? In addressing these questions, contrasts are presented with local unmined soils and with the results of previous studies conducted at this mine (Cook 2012; Spain et al. 2006; 2009a; b; 2015).

\section{Materials and methods}

\section{Study location}

The studies reported here were carried out on restored tropical forest sites at the Gove bauxite mine; the mine is located at $12^{\circ} 16^{\prime} \mathrm{S}, 136^{\circ} 49^{\prime} \mathrm{E}$ on the Gove Peninsula in the Northern Territory of Australia and surrounds the airport. Climatic conditions at the site are monsoonal with $c .90 \%$ of average annual rainfall $(1457 \mathrm{~mm})$ falling within the months November to April. Total annual pan evaporation at this site averages $2153 \mathrm{~mm}$. Mean monthly maximum temperatures during the hottest (December) and coldest (July) months are $33{ }^{\circ} \mathrm{C}$ and $28^{\circ} \mathrm{C}$, respectively (Bureau of Meteorology 2015).

\section{Vegetation and soil properties}

The unmined soils of the mine lease area $\left(>500 \mathrm{~km}^{2}\right)$ largely support tall open forests, mostly dominated by Eucalyptus tetrodonta F.Muell. and Eucalyptus miniata A.Cunn. ex Schauer with two highly biodiverse underlying strata dominated, respectively, by shrubs and perennial grasses (Spain et al. 2015). Extensive fires typically initiated by lightning and through traditional burning practices are a regular feature of this region 
(Department of Sustainability, Environment, Water, Population and Communities 2008).

\section{Unmined soils}

These highly-weathered soils are classified as bauxitic dystrophic Red Kandosols (Isbell 1996), Oxisols (Soil Survey Staff 1999) or Ferralsols (IUSS Working Group WRB 2015) and are known for their low P status: combined values for unfertilized oxisols worldwide indicate mean Pt concentrations of $220 \mathrm{mg} \mathrm{kg}^{-1}$, se 29, $n=20$ (Negassa and Leinweber 2009; Yang and Post 2011). Total $P$ stocks in the surface $0-30 \mathrm{~cm}$ of the soils local to the mine area are predicted to be c. 0.3$0.4 \mathrm{t} \mathrm{ha}^{-1}$, substantially less than the average Australian topsoil stock of c. $1.0 \mathrm{t} \mathrm{ha}^{-1}$ (Viscarra Rossel and Bui 2016). Landscape relief is low throughout the study area and average solum depth over the indurated layer is $c$. $0.70 \mathrm{~m}$ (O’Keefe 1992).

The unmined soils are extremely permeable, mildly acid (approximate $\mathrm{pH}$ range: 5.6 to 6.2, 1:5 soil solution ratio, $\left.0.01 \mathrm{M} \mathrm{CaCl}_{2}\right)$ and non-saline. Near-surface $(0-$ $5 \mathrm{~cm}$ ) total (dry combustion chromatography) $\mathrm{C}$ and $\mathrm{N}$ concentrations typically range from c. 20 to $30 \mathrm{~g} \mathrm{~kg}^{-1} \mathrm{C}$ and from c. 0.01 to $0.09 \mathrm{~g} \mathrm{~kg}^{-1} \mathrm{~N}$, respectively; $\mathrm{C} / \mathrm{N}$ ratios range from 17 at depth to more than 35 at the surface. The clay-sized fraction is dominated by kaolinite with gibbsite and the oxides and hydroxides of $\mathrm{Fe}$ and Al. Cation exchange capacity (CEC, silver thiourea method) is closely dependent on $\mathrm{pH}$ and on soil organic matter concentrations.

\section{Restored soils}

The rapidly developing soils of the restored areas are gravel-rich and highly permeable, with permeability increasing with restoration period. Over all depths, the $\mathrm{pH}\left(\mathrm{CaCl}_{2}\right)$ of the restored soils ranged from 4.89 to 6.15 , and was highly correlated $(r=-0.743, P<0001$, $n=31$ ) with the natural logarithm of the $C$ concentration. Over the $0-10 \mathrm{~cm}$ depth range and from one to 26 years following restoration, concentrations of estimated total $\mathrm{C}$ and total $\mathrm{N}$ increased, respectively, from c. 7.0 to $42.0 \mathrm{~g} \mathrm{~kg}^{-1}$ and from $0.04 \mathrm{~g} \mathrm{~kg}^{-1}$ to $2.23 \mathrm{~g} \mathrm{~kg}^{-1}$. The $\mathrm{C} / \mathrm{N}$ ratio of the restored soils ranged from 17 at depth to 29 at the surface, with greater values in most mine floor samples (Spain et al. 2015). Much of the C present in the replaced topsoil is likely to occur as pyrogenic C (Reisser et al. 2016) and other decomposition-resistant compounds.

Further and supporting details can be found in Spain et al. (2015).

Mining and restoration processes

Bauxite is mined using a simple strip-mining process integrated with a consistent restoration program that aims to restore a eucalypt-dominated open forest of similar composition and structure to that present prior to mining (Spain et al. 2015). Vegetation is felled and burned, remaining material is removed, and the site 'fallowed' for 2-3 years. The A and upper B horizons (up to c. $30 \mathrm{~cm}$ ) are then transported to form the topsoil layer of another previously mined site and the subsoil is removed to permit mining. Following mining, the subsoil and topsoil are replaced, and the site is deep ripped. Tree, shrub and grass seeds are broadcast together with a surface application of single superphosphate equivalent to c. $25 \mathrm{~kg} \mathrm{P} \mathrm{ha}{ }^{-1}$. No subsequent cultivation is undertaken.

The mean concentrations of $\mathrm{Pt}$, total $\mathrm{C}$ and total $\mathrm{N}$ in the $0-10 \mathrm{~cm}$ interval in the soil of a cleared, fallowed site prior to transport to a new site were, respectively, $206 \mathrm{mg} \mathrm{kg}^{-1}$ (se 11), $14.25 \mathrm{~g} \mathrm{~kg}^{-1}$ (se 1.95) and $0.52 \mathrm{~g} \mathrm{~kg}^{-1}$ (se 0.10$)$ ( $n=4$ for all). In the first year following site restoration processes, the estimated $\mathrm{C}$ and $\mathrm{N}$ concentrations $(0-10 \mathrm{~cm})$ were $13 \mathrm{~g} \mathrm{~kg}^{-1}$ and $0.46 \mathrm{~g} \mathrm{~kg}^{-1}$, respectively, and increased to $42 \mathrm{~g} \mathrm{~kg}^{-1}$ and $2.3 \mathrm{~g} \mathrm{~kg}^{-1}$ at 26 years, again respectively. A detailed description of the restoration process and the properties of the undisturbed and restored soils are presented in Spain et al. (2015).

\section{Soil sampling and preparation}

At the end of the monsoon season, in late April 2002, the developing soils and the upper $0-5 \mathrm{~cm}$ intervals of the underlying bauxitic indurated layer were sampled from pits randomly located along $100 \mathrm{~m}$ transects set out in a 26-year chronosequence of seven similarly restored study sites $(1,2,4,8,13,20,26$ years) and in an unmined native forest site $(\mathrm{AB})$ of medium profile depth ( $0.66 \mathrm{~m}$ to the top of the bauxitic layer). Samples were taken from the pit walls at the depth intervals listed in Appendix Table 5, based on observed morphological and textural features of the materials present (Spain et al. 2015). 
Within each pit, compound samples were taken of materials at several locations from a c. $0.75 \mathrm{~m}$ length of a single pit face over the described depth intervals. These sampling intervals were based on the homogeneity of the included materials using such measures as colour, texture, structure and, close to the surface, the presence of organic matter, organic matter staining and such biological constructs as termite and ant galleries, storage chambers and earthworm casts. At the longest restored sites, a near-surface layer of the mineral soils developed that contained substantial incorporated and decomposed organic materials; this was sampled separately where it was practical to do so.

In preparation for $\mathrm{P}$ fractionation analyses, sample materials were air dried, sieved $(<2 \mathrm{~mm}$ ECD) and macroscopically observable root and other plant and animal materials were removed (Condron and Newman 2011). In addition, soils sampled from the 0 $4 \mathrm{~cm}$ layer of selected time domains in October 2002 were used to identify the chemical nature of soil organic $\mathrm{P}$ using solution ${ }^{31} \mathrm{P}$ nuclear magnetic resonance (NMR) spectroscopy. These included sites restored for $2,4,8$, $13,17,20$ and 26 years and two unmined native forest sites, one unburned (UB); the other (AB) had been burned approximately two years prior to sampling. These soils were prepared for chemical analysis as above.

Post-restoration plant community and litter development

The restored sites develop from bare soil at sowing and progress through transitional stages of dominance by grasses (1-5 years) with shrubs gradually assuming dominance ( $>5-8$ years), followed by a phase of declining shrubs with emerging small eucalypt trees $(>8-$ 13 years) and finally emerging dominance by eucalypts at sites restored for more than 13 years. Canopy and litter closure typically occur between 8 and 13 years. The plant community progression implies nutritional shifts associated with initial dominance by the arbuscular mycorrhizal grasses and nitrogen-fixing acacia shrubs transitioning to the mixed arbuscular and ectomycorrhizal associations associated with the more mature forests (Reddell and Milnes 1992). Substantial litter layers (to c. $36 \mathrm{t} \mathrm{ha}^{-1}$ dry weight at 26-28 years) form at the restored sites (Cook 2012; Spain et al. 2006, 2015), particularly after canopy closure. Based on estimates of mean litter P concentration (302 mg kg-1) and biomass $\left(2.52 \mathrm{~kg} \mathrm{~m}^{-2}\right)$ at a 26 -year restored site, the litter standing crop of $\mathrm{P}$ was estimated c. $8 \mathrm{~kg} \mathrm{ha}^{-1}$.

The restored sites are typically protected from burning although the surrounding native forest areas are frequently burned.

Analytical methods

\section{Total elemental analyses}

Total P concentrations of the sample fine earth $(<$ $2 \mathrm{~mm}$ ) fraction were determined at the Advanced Analytical Centre, James Cook University, Townville using XRF spectrographic analysis of fine-ground, pressed sample materials. To establish more robust correlations with restoration period, these were supplemented with Pt records $(0-10 \mathrm{~cm})$ from 18 further sites obtained from previous unpublished studies and analysed using similar methods (see also Spain et al. 2015). Total $\mathrm{C}$ and total $\mathrm{N}$ values were determined using a Europa 20-20 isotope mass spectrometer with an ANCA preparation system.

\section{Phosphorus fractionation}

The $\mathrm{P}$ fractionation studies were carried out at James Cook University using the modified Hedley fractionation method of Tiessen and Moir (1993) to fractionate sample P (see Appendix Fig. 1 for extraction sequence and fraction titles). Briefly, following the addition of solution and overnight shaking, tubes were centrifuged (3000 rpm for $c .7 \mathrm{~min}$ ) and the supernatant decanted prior to the addition of the subsequent extractant. Except where otherwise indicated, P concentrations in the sample solutions were determined spectrophotometrically as the phospho-molybdate complex using standard methods (Department of the Environment 1993). Detection limits for each extraction were determined by measuring digestion blanks in triplicate and expressing the limit of detection as three times the standard deviation of the blanks (Taylor 1987). The inorganic fractions Resin $P$, Bicarbonate $P_{i}$, Hydroxide $P_{i}$, Dilute $\mathrm{HCl} P_{i}$ and Conc. $\mathrm{HCl} P_{i}$ were measured directly on the extracts. Concentrations of the organic $\mathrm{P}$ components (Bicarbonate $P_{o}$, Hydroxide $P_{o}$ and Conc. $\mathrm{HCl} P_{o}$ ) for each fractionation stage were obtained as the difference between the total concentration of the component following digestion and that of the inorganic component. 
These fractions are considered as 'chemically defined', but have been broadly associated with various classes of P.

The putative availabilities of the extracted fractions to plants and microorganisms are presented in Cross and Schlesinger (1995) and Condron and Newman (2011). Labile $P$ is the sum of the concentrations of Resin $P$, Bicarbonate $P_{i}$ and Bicarbonate $P_{o}$ and is considered to be the $\mathrm{P}$ biologically available over short periods, ranging up to some months. Intermediate $P$ is the sum of Hydroxide $P_{i}$, Hydroxide $P_{o}$ and Dilute $\mathrm{HCl} P_{i}$ : this fraction is viewed as available in the medium term, perhaps at the scale of a growing season. The sum of Conc. $\mathrm{HCl} \mathrm{P}_{i}$ and Conc. $\mathrm{HCl} \mathrm{P}_{o}$ is Long-term $\mathrm{P}$, which is considered as only slowly available, perhaps at a scale of many years. Residual $P$ is perceived as occluded and unavailable, except possibly over extremely long periods. Nonetheless, at least some part of this fraction may become available over relatively short time periods (Condron and Newman 2011). Biological $P$ is defined as the sum of Bicarbonate $P_{o}$, Hydroxide $P_{o}$ and Conc. $\mathrm{HCl} \mathrm{P}_{\mathrm{o}}$. Labile $P$, Intermediate $P$, Long-term $P$ and Biological $P$ fractions are here described as 'derived' fractions and are defined as follows:

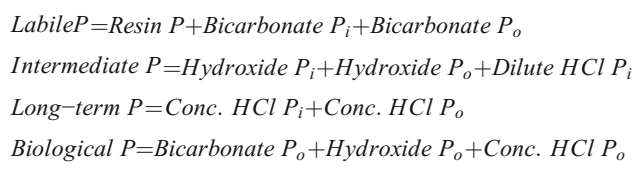

Soil Pt concentrations determined using concentrated $\mathrm{H}_{2} \mathrm{SO}_{4} / \mathrm{H}_{2} \mathrm{O}_{2}$ (Tiessen and Moir 1993) gave an average value of $70.2 \%$ (se $1.8, n=36$ ) of those determined using XRF analysis. Residual $P$ was therefore calculated here as the difference between Pt determined by XRF spectrographic analysis and the sum of the fractions up to and including Conc. $\mathrm{HCl} \mathrm{P}$.

\section{NaOH-EDTA extraction}

The NaOH-EDTA extraction technique was used to extract soil organic $\mathrm{P}$ prior to its characterisation using solution ${ }^{31} \mathrm{P}$ NMR spectroscopy. The NaOH-EDTA extraction technique used in this study was based on the method of Cade-Menun and Preston (1996), but at a 1:4 soil to solution ratio as recommend by McLaren et al. (2015a) for soils with low concentrations of organic P. Briefly, $3 \mathrm{~g}$ soil samples were extracted with $12 \mathrm{~mL}$ of
$0.25 \mathrm{M} \mathrm{NaOH}+0.05 \mathrm{M} \mathrm{Na}_{2}$-EDTA solution for $16 \mathrm{~h}$. The extracts were then centrifuged at $5000 \mathrm{rpm}$ for $20 \mathrm{~min}$, and the supernatant passed through a Whatman no. 42 filter paper. A $3.5 \mathrm{~mL}$ aliquot of the filtrate was frozen at $-80^{\circ} \mathrm{C}$, and then lyophilised and weighed (on average $112 \mathrm{mg}$ of lyophilised material) prior to NMR analysis. Concentrations of total $\mathrm{P}$ in the remaining filtrate were determined using inductively coupled plasma-optical emission spectroscopy (ICP-OES), whereas concentrations of molybdate-reactive P (MRP - analogous with inorganic P) was determined using the malachite green method of Ohno and Zibilske (1991). The difference between concentrations of total $\mathrm{P}$ via ICP-OES and MRP was taken as molybdate-unreactive $\mathrm{P}$ (MUP - analogous with organic $\mathrm{P}$ ).

\section{Sample preparation for NMR analysis}

Preparation of lyophilised material for solution ${ }^{31} \mathrm{P}$ NMR analysis was based on a modification of the method of Vincent et al. (2013). Briefly, $600 \mu \mathrm{L}$ of $0.25 \mathrm{M} \mathrm{NaOH}+0.05 \mathrm{M} \mathrm{Na}_{2}$-EDTA solution was added to each centrifuge tube, placed on a vortex mixer for $2 \mathrm{~min}$, and then centrifuged at $5000 \mathrm{rpm}$ for $20 \mathrm{~min}$. A $500 \mu \mathrm{L}$ aliquot of the supernatant was transferred to a $1.5 \mathrm{~mL}$ microcentrifuge tube, and then spiked with a $50 \mu \mathrm{L}$ aliquot of $32.3 \mathrm{~m} M$ methylenediphosphonic acid (MDP: Sigma-Aldrich, M9508) and $75 \mu \mathrm{L}$ of sodium deuteroxide solution 40 wt. $\%$ in $\mathrm{D}_{2} \mathrm{O}$ (NaOD: SigmaAldrich, 372,072). The microcentrifuge tube was then vortexed for $10 \mathrm{~s}$ and transferred to a $5 \mathrm{~mm}$ NMR tube prior to NMR analysis.

In addition, the NMR spectra in the Year 26 soil and both native forest soils (UB and AB) exhibited considerable line broadening for all peaks: probably due to high sample viscosity. The extraction and preparation of these soils was repeated as previously described, except additional NaOH-EDTA solution was added to the lyophilised material until spectral quality was improved (Cade-Menun and Liu 2014). Samples from site year 26, $\mathrm{UB}$ and $\mathrm{AB}$ required 1.5, 1.2 and $0.9 \mathrm{~mL}$ of $\mathrm{NaOH}-$ EDTA solution, respectively.

\section{Solution ${ }^{31} P$ NMR analysis}

Solution ${ }^{31} \mathrm{P}$ NMR spectroscopy was carried out using a Bruker Avance III HD 500 NMR spectrometer (Bruker Corporation; Billerica, MA) at the combined NMR facility of the Laboratory of Inorganic Chemistry 
(Hönngerberg, ETH Zürich). The NMR spectrometer was set at a ${ }^{31} \mathrm{P}$ frequency of $202.5 \mathrm{MHz}$ with gated broadband proton decoupling, a $90^{\circ}$ pulse of $14 \mu \mathrm{s}$, and the acquisition of 4096 scans with an average time of $14 \mathrm{~h} 16$ min per sample. An inversionrecovery experiment was initially carried out to determine the spin-lattice relaxation times $\left(\mathrm{T}_{1}\right)$ of ${ }^{31} \mathrm{P}$ in order to calculate the minimum recycle delay for each soil. In general, the $T_{1}$ relaxation times ranged in descending order: orthophosphate $>$ phosphonate (added MDP standard) $>$ phosphomonoesters. Concentrations of phosphodiesters and pyrophosphate were too low for a reliable measure of their $T_{1}$ relaxation time. However, McDowell et al. (2006) reported their relaxation times were similar or lower than those of phosphomonoesters. Therefore, recycle delays were set at least five times the $T_{1}$ relaxation time of the added MDP standard so that more scans could be collected (from 1024 to 4096) in order to double the signal-to-noise ratio, but still quantitatively determine the $\mathrm{P}$ species of importance to the current study (i.e., organic P).

All spectra were processed within TopSpin ${ }^{\circledR}$ software (Bruker Corporation; Billerica, MA).

Quantification of $\mathrm{P}$ species in soil extracts via solution ${ }^{31} \mathrm{P}$ NMR spectroscopy was carried out as previously described by Doolette et al. (2011a) as the integral of the added MDP of known concentration is directly proportional to all other integrals in the NMR spectrum. Briefly, the integrals of all ${ }^{31} \mathrm{P}$ signals in the NMR spectrum were determined (except that of orthophosphate $-\delta 5.6$ to $5.3 \mathrm{ppm}$ ). In general, this included the following regions: the added MDP ( $\delta 17.3$ to $16.2 \mathrm{ppm})$, phosphomonoesters ( $\delta 5.2$ to $2.8 \mathrm{ppm}$ ), phosphodiesters ( $\delta-0.7$ to $-1.5 \mathrm{ppm})$, and pyrophosphate $(\delta-4.6$ to $-4.9 \mathrm{ppm})$. Concentrations of organic $\mathrm{P}$ were calculated by summing the pools of phosphomonoesters and phosphodiesters. Peak assignments were based on spiking experiments and comparisons with previous studies (Doolette et al. 2009; McLaren et al. 2015b; Turner et al. 2003a). Quantification of P species within the phosphomonoester region using spectral deconvolution was not carried out due to a low signal-to-noise ratio.

Data presentation and analysis

Total P results include data from the current study, Spain et al., 2009a, b) and unpublished reports (AV Spain). The $\mathrm{P}$ fractions are considered in terms of derived and chemically defined fractions and in terms of the interrelationships among the fractions and with other properties of the materials sampled. In the analysis of the data derived from the Hedley fractionation, values lower than the detection limit were arbitrarily assigned a value of $0.005 \mathrm{mg} \mathrm{kg}^{-1}$. For purposes of statistical analysis and discussion, sample values from the restored sites were grouped into four depth ranges: $0-5 \mathrm{~cm},>5-10 \mathrm{~cm}$, from $>10 \mathrm{~cm}$ to the top of the mine floor and the upper $0-5 \mathrm{~cm}$ interval of the mine floor. The near-surface soils of the unmined native forest site $(A B)$ were sampled over the interval $0-12 \mathrm{~cm}$ and the deepest sample was taken from the upper $5 \mathrm{~cm}$ interval of the bauxitic layer.

Analysis of deviance log-linear models were used to estimate the change of each property over time and how that varied with depth. The variance of the responses increased with their mean values, and thus the error variance was modelled as proportional to the mean response. For analyses where there was no significant interaction between time and depth, the simpler additive model in time and depth was used. These analyses were conducted using $\mathrm{R}$ software ( $\mathrm{R}$ Core Team 2016).

The probabilities arising from statistical testing are considered significant at $P<0.05$, unless explicitly indicated otherwise.

\section{Results}

This section presents the analytical results for Pt (Appendix Table 5) and the Hedley fractionation (Appendix Table 6), together with the interrelations between the fractions and other physical and chemical properties. It also presents the properties of the organic $\mathrm{P}$ present within the developing surface soils. Contrasts are drawn with similar results obtained from local native forest sites, unburned and burned.

Total phosphorus

Figure 1a presents the Pt concentrations of 31 soils and mine floor materials combined over four depth intervals from the seven restored sites. An analysis of deviance of all sample Pt data was carried out to test the significances of the effects of restoration period and depth (Table 1). While Pt increased in the $0-5$ and $>5-$ $10 \mathrm{~cm}$ intervals, it did not vary significantly with 

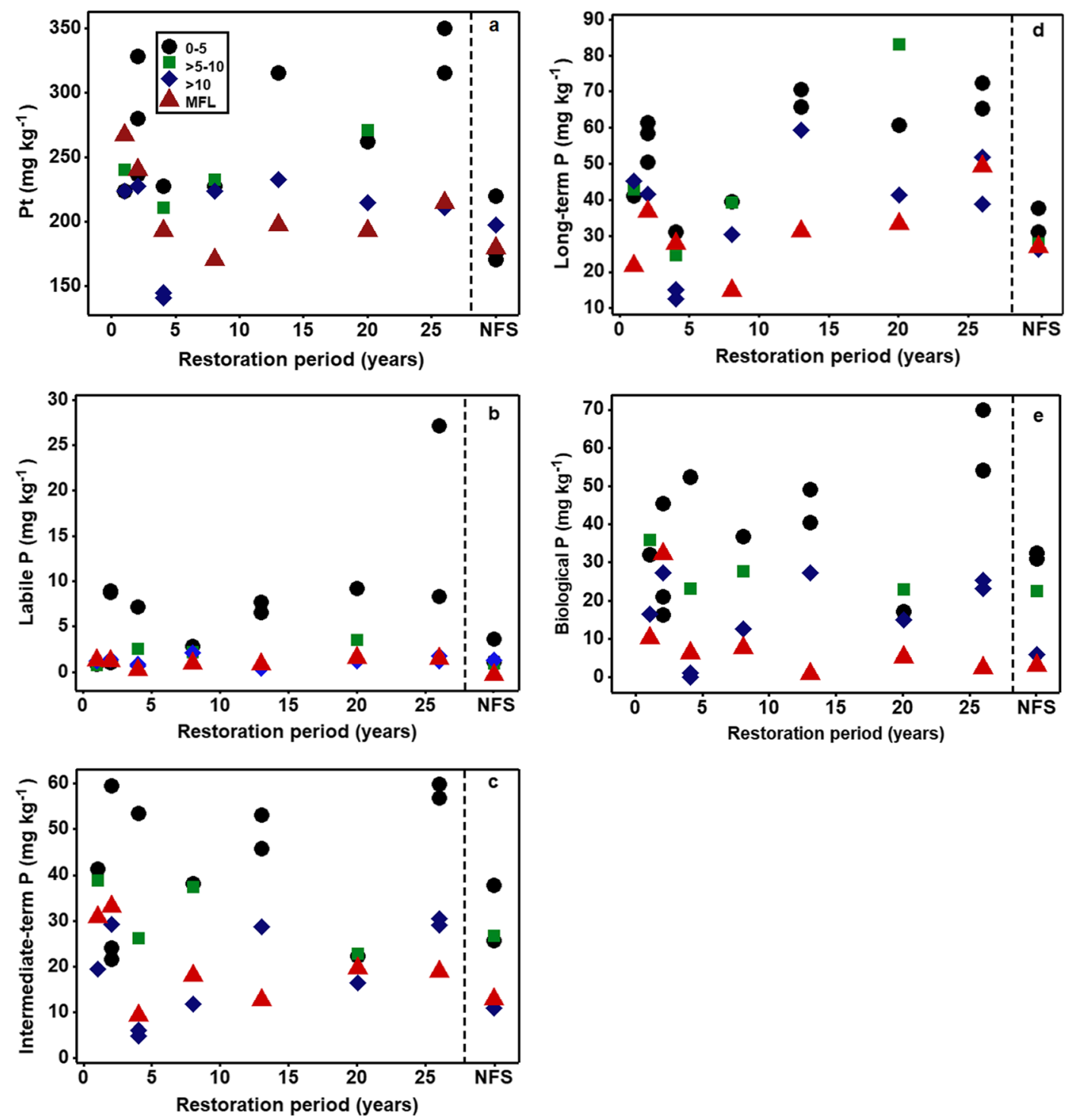

Fig. 1 Concentrations of total $\mathrm{P}$ and the derived fractions in relation to restoration period and depth in the restored soils and in an undisturbed native forest soil (NFS site AB, MFL mine floor) (sampled May 2002)

restoration period, although the effect of depth was highly significant; there was no significant interaction between restoration period and depth. A clear depth trend was confirmed: Pt in the surface $0-5 \mathrm{~cm}$ interval was not significantly different from that in the $>5-10 \mathrm{~cm}$ layer $(t=0.86, n=15, P=0.400)$, but was greater than that of the soils $>10 \mathrm{~cm}$ in depth $(t=3.96, n=19$, $P<0.001)$ and the mine floor materials $(t=3.50, n=$ $17, \mathrm{P}<0.001)$.

Mean Pt concentrations in the $0-10 \mathrm{~cm}$ interval of the seven restored profiles ranged from 219 to $332 \mathrm{mg} \mathrm{kg}^{-1}$, with an overall mean of $269 \mathrm{mg} \mathrm{kg}^{-1}$ (se 12, $\mathrm{n}=15$ ).
The mean Pt concentration of these soils at depths greater than $10 \mathrm{~cm}$ was $203 \mathrm{mg} \mathrm{kg}^{-1}$ (se 12,n=9) and in the mine floor samples was $210 \mathrm{mg} \mathrm{kg}^{-1}$ (se 12, $n=$ 7). In the single native forest profile ( $\mathrm{AB}$ ) examined, $\mathrm{Pt}$ concentration in the $0-2.5 \mathrm{~cm}$ interval was $219 \mathrm{mg} \mathrm{kg}^{-1}$ and ranged from 170 to $197 \mathrm{mg} \mathrm{kg}^{-1}$ below this depth.

Combining the above data with unpublished Pt estimates from 18 other sites restored from one to 30 years (Spain et al. 2009a, b and unpublished reports) and sampled over a depth range of $0-10 \mathrm{~cm}$ gave a mean value of $316 \mathrm{mg} \mathrm{kg}^{-1}$ ( $\left.\mathrm{se}=5, n=91\right)$. A similar estimate from four local native forest sites was $278 \mathrm{mg} \mathrm{kg}^{-1}$ (se = 
$11, n=16)$. Concentrations of Pt in the 18 restored sites were weakly positively correlated with restoration period $(r=0.298, P<0.005)$.

Sequential phosphorus fractionation

Figures $1 \mathrm{~b}-\mathrm{d}$ present, respectively, the concentrations of Labile P, Intermediate $P$ and Long-term $P$ in relation to rehabilitation period and depth. Similarly, Fig. 1e presents the concentrations of Biological $P$. Figures $2 \mathrm{a}, \mathrm{b}$ present the concentrations of Resin $P$ and Bicarbonate $P_{o}$ in the upper $0-5 \mathrm{~cm}$ interval and Fig. 2c-e present the concentrations of Conc. $\mathrm{HCl} P_{i}$ in, respectively, the $0-5 \mathrm{~cm},>10 \mathrm{~cm}$ and mine floor layers, also with respect to restoration period and sample depth. The fitted functions are presented to these relationships.

Analysis of deviance was conducted of the derived fractions, Residual $P$ and selected chemically defined fractions in relation to effects of restoration period, depth and their interactions (Table 1). Only Labile $P$ and Long-term $P$ showed significant variation with restoration period; increasing concentrations of Labile $P$ with restoration period were due to those of Resin $P$ and Bicarbonate $P_{o}$, largely in the upper $0-5 \mathrm{~cm}$ interval; Bicarbonate $P_{i}$ concentrations were particularly low and did not differ significantly with restoration period or with depth. Intermediate $P$ concentrations (Fig. 1c) showed a significant effect of depth due to significant depth variation in both Hydroxide $P_{i}$ and Hydroxide $P_{o}$, both $P<0.01$. An estimated mean value for the $0-10 \mathrm{~cm}$ interval is $40 \mathrm{mg} \mathrm{kg}^{-1}$, se $4, n=15$, approximately twice the mean concentrations of the underlying materials. Long-term $P$ concentrations (Fig. 1d) increased significantly with restoration period, both in the $0-10 \mathrm{~cm}$ interval and at greater depths, notably in the mine floor; this was due to increasing Conc. $\mathrm{HCl}$ $P_{i}$ values in all depth intervals, including the mine floor (Fig. 2a-e). As considered below, Conc. $\mathrm{HCl} \mathrm{P}_{i}$ values were virtually identical to those of Long-term $P$. Residual $P$ concentrations did not vary significantly with either restoration period or depth and a mean value over all restored sites was $160 \mathrm{mg} \mathrm{kg}^{-1}$, se 4 . No significant interactions were found between restoration period and depth in the analyses of the derived fractions although significant interactions occurred between restoration period and depth in the analysis of Resin P and Conc. $\mathrm{HCl} \mathrm{P}$.
Table 1 Analysis of deviance of the effects of restoration period and depth for total $\mathrm{P}$, the derived fractions and selected chemically defined fractions ( $n=31$ for restored soils) (sampled May 2002)

\begin{tabular}{|c|c|c|c|c|}
\hline Fraction & Factor & $\mathrm{F}$ & $\mathrm{df}$ & $\mathrm{P}$ \\
\hline \multicolumn{5}{|l|}{ Total P } \\
\hline \multirow[t]{3}{*}{$\mathrm{Pt}$} & Years & 2.32 & 1,29 & 0.141 \\
\hline & Depth & 8.28 & 3,26 & $<0.001$ \\
\hline & Interaction & 1.77 & 3,23 & 0.181 \\
\hline \multicolumn{5}{|l|}{ Derived fractions } \\
\hline \multirow[t]{3}{*}{ Labile $P$} & Years & 22.60 & 1,29 & $<0.001$ \\
\hline & Depth & 25.78 & 3,26 & $<0.001$ \\
\hline & Interaction & 0.47 & 3,23 & 0.708 \\
\hline \multirow[t]{3}{*}{ Intermediate $P$} & Years & 0.68 & 1,29 & 0.417 \\
\hline & Depth & 8.68 & 3,26 & $<0.001$ \\
\hline & Interaction & 1.25 & 3,23 & 0.314 \\
\hline \multirow[t]{3}{*}{ Long-term $P$} & Years & 9.40 & 1,29 & 0.005 \\
\hline & Depth & 5.27 & 3,26 & 0.006 \\
\hline & Interaction & 0.14 & 3,23 & 0.936 \\
\hline \multirow[t]{3}{*}{ Residual P } & Years & 0.16 & 1,29 & 0.690 \\
\hline & Depth & 2.13 & 3,26 & 0.124 \\
\hline & Interaction & 2.42 & 3,23 & 0.092 \\
\hline \multirow[t]{3}{*}{ Biological P } & Years & 0.83 & 1,29 & 0.373 \\
\hline & Depth & 7.33 & 3,26 & 0.001 \\
\hline & Interaction & 1.08 & 3,23 & 0.378 \\
\hline \multicolumn{5}{|c|}{ Chemically defined fractions } \\
\hline \multirow[t]{3}{*}{ Resin $P$} & Years & 7.77 & 1,26 & 0.010 \\
\hline & Depth & 4.36 & 3,27 & 0.014 \\
\hline & Interaction & 3.24 & 3,23 & 0.041 \\
\hline \multirow[t]{3}{*}{ Bicarbonate $P_{o}$} & Years & 5.54 & 1,26 & 0.0275 \\
\hline & Depth & 9.97 & 3,27 & $<0.001$ \\
\hline & Interaction & 0.46 & 3,23 & 0.709 \\
\hline \multirow[t]{3}{*}{ Conc. $\mathrm{HCl} \mathrm{P} i$} & Years & 11.00 & 1,26 & 0.003 \\
\hline & Depth & 3.04 & 3,27 & 0.049 \\
\hline & Interaction & 3.56 & 3,23 & 0.030 \\
\hline
\end{tabular}

Biological $P$ values (Fig. 1e) did not differ significantly with restoration period although there was a very highly significant depth effect. A mean concentration for the $0-10 \mathrm{~cm}$ interval is $36 \mathrm{mg} \mathrm{kg}^{-1}$ (se $4, n=15$ ), markedly greater than the concentrations present in the underlying materials. Low values in the surface soils of the 20-year restored site were due to low Hydroxide $P_{o}$ concentrations.

The Labile and Intermediate $P$ fractions of the soil layers were dominantly organic while Long-term $P$ was 

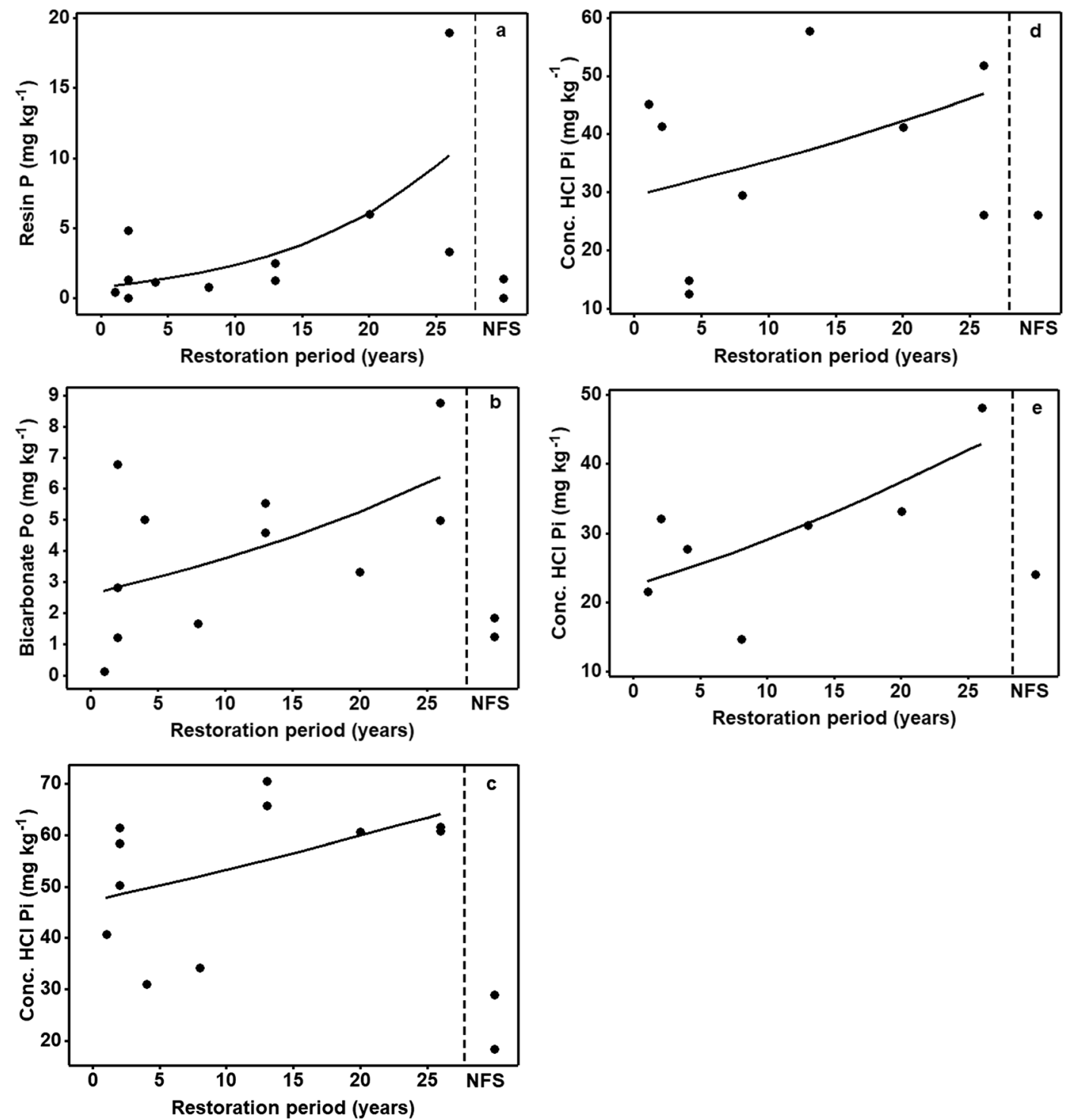

Fig. 2 Concentrations of Resin $P$ (a) and Bicarbonate $P_{o}$ (b) in the 0-5 cm interval and of Conc. $\mathrm{HCl} P_{i}$ in the $0-5 \mathrm{~cm}$ (c), $>10 \mathrm{~cm}$ (d) and upper mine floor (e) materials in relation to restoration period

and depth in the restored soils and in an undisturbed native forest soil (NFS site AB) (sampled May 2002)

dominantly inorganic. Excluding the mine floor layer and based on mean concentrations, Bicarbonate $P_{o}$ comprised $56 \%$ of Labile $P$ and Hydroxide $P_{o}$ formed $79 \%$ of Intermediate P. In contrast, Conc. $\mathrm{HCl} P_{o}$ comprised only $2 \%$ of Long-term $P$, with highest values associated with a few near-surface samples from longer-restored sites and from the native forest site (AB). Organic P percentages in two components were lower in the mine floor layer: Bicarbonate $P_{o}$ formed $c$. $40 \%$ of Labile $P$, Hydroxide $P_{o}$ comprised a similar

percentage of Intermediate $P$ while Conc. $\mathrm{HCl} P_{o}$ formed 3\% of Long-term P.

Particularly in the 20 and 26-year sites, near-surface Labile $P$ and Long-term $P$ concentrations mostly exceeded values at equivalent depths in the native forest site (AB). Concentrations of Intermediate $P$ at all depths and of Labile $P$ and Long-term $P$ at depths greater than $10 \mathrm{~cm}$ were generally equivalent to those of the native forest site. Residual $P$ values in the restored surface 0 $5 \mathrm{~cm}$ interval were higher than in the native forest soil 
(AB). Biological $P$ values from the $0-10 \mathrm{~cm}$ interval of the 26-year-restored site were substantially greater than those of the $0-12 \mathrm{~cm}$ interval of the native forest site; concentrations in the native forest profile $\mathrm{AB}$ were minimal below this depth interval.

Relationships between total phosphorus and the derived fractions with other soil properties

In the restored soil materials, concentrations of Pt, $\mathrm{La}$ bile, Intermediate, Long-term, Biological and Residual $P$ over all depths were positively correlated with those of $\mathrm{C}$ and $\mathrm{N}$ and were negatively correlated with the clay concentration (Table 2, Appendix Table 5). None of first four derived fractions were significantly $(P>0.05$ for all) correlated with the $\mathrm{C} / \mathrm{N}$ ratio. Total $\mathrm{P}$ was not significantly correlated with the concentration of silt and only Biological $P$ was positively related to silt concentration.

The ratios of $\mathrm{C} /$ Biological $\mathrm{P}$ in the upper $10 \mathrm{~cm}$ intervals of the restored soils varied little with restoration period and a mean value for these soils was 749 (se 159, $n=15$ ); some high values were found in the surface soils of the longer restored sites. Values in the native forest site $\mathrm{AB}$ were 1054 in the surface $0-2.5 \mathrm{~cm}$ interval and c. 373 in the interval $2.5-$ $12 \mathrm{~cm}$. None of the four derived fractions were significantly $(\mathrm{P}>0.05$ for all) correlated with $\mathrm{C} /$ Biological $\mathrm{P}$ ratio.

In the mine floor materials, Biological $P$ was strongly positively and significantly correlated with the concentrations of $\mathrm{C}(r=0.931, P=0.002), \mathrm{N}(r=0.897, P=$ $0.006)$ and silt $(r=0.820, P=0.024)$.
Table 3 Concentrations $\left(\mathrm{mg} \mathrm{kg}^{-1}\right)$ of $\mathrm{P}$ in $\mathrm{NaOH}-\mathrm{EDTA}$ extracts $(1: 4$ soil to solution ratio) of the soils $(0-4 \mathrm{~cm})$ of the chronosequence of restored sites, a long unburned native forest site (UB), and a previously burned native forest site (AB) (sampled October 2002)

\begin{tabular}{llll}
\hline \multirow{2}{*}{ Restoration period (years) } & \multicolumn{3}{l}{ NaOH-EDTA extractable $\mathrm{P}\left(\mathrm{mg} \mathrm{kg}^{-1}\right)$} \\
\cline { 2 - 4 } & Total & MRP & MUP \\
\hline 2 & 43.3 & 30.2 & 13.1 \\
4 & 37.6 & 16.7 & 20.9 \\
8 & 40.9 & 15.2 & 25.7 \\
13 & 49.3 & 32.7 & 16.6 \\
17 & 36.6 & 19.7 & 16.9 \\
20 & 39.6 & 27.1 & 12.5 \\
26 & 38.3 & 27.9 & 10.4 \\
Native forest sites & & & \\
UB & 44.9 & 40.1 & 4.9 \\
AB & 27.5 & 25.7 & 1.8 \\
\hline
\end{tabular}

MRP refers to molybdate-reactive $\mathrm{P}$, and MUP refers to molybdate-unreactive $P$

Chemical nature of soil organic phosphorus

Concentrations of total $\mathrm{P}$ in $\mathrm{NaOH}-\mathrm{EDTA}$ extracts across all restoration periods were on average $40 \mathrm{mg} \mathrm{kg}^{-1}$, which was similar to that of the unburned native forest site UB, but slightly higher than that of the burned native forest site $\mathrm{AB}$ (Table 3). Concentrations of inorganic $\mathrm{P}$ and organic $\mathrm{P}$ across all restoration periods were variable and extremely low: on average 25 and $16 \mathrm{mg} \mathrm{kg}^{-1}$, respectively. In general, when concentrations of inorganic $\mathrm{P}$ were slightly lower compared to the average, concentrations of organic $\mathrm{P}$ were slightly higher and vice versa. Concentrations of organic $\mathrm{P}$

Table 2 Pearson product moment correlations (with associated $\mathrm{P}$ values) between total $\mathrm{P}$, the derived fractions and four selected properties of the restored soils, excluding mine floor records $(n=24 ; n=23$ for Biological P) (sampled May 2002)

\begin{tabular}{llllll}
\hline Property & Total P & Labile $P$ & Intermediate $P$ & Long-term P & Biological P \\
\hline $\mathrm{C}$ & 0.688 & 0.956 & 0.564 & 0.508 & 0.659 \\
& $<0.001$ & $<0.001$ & 0.004 & 0.011 & 0.498 \\
$\mathrm{~N}$ & 0.682 & 0.959 & 0.577 & 0.013 & 0.684 \\
& $<0.001$ & $<0.001$ & 0.003 & -0.635 & -0.001 \\
Clay (\%) & -0.672 & -0.571 & -0.548 & 0.001 & 0.003 \\
& $<0.001$ & 0.004 & 0.006 & 0.175 & 0.430 \\
Silt $(\%)$ & 0.221 & 0.388 & 0.390 & 0.414 & 0.036 \\
\hline
\end{tabular}


Year 2

Year 4

Year 8

Year 13

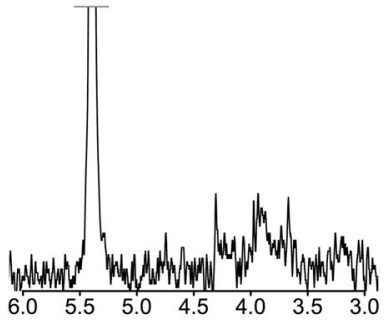

Year 17

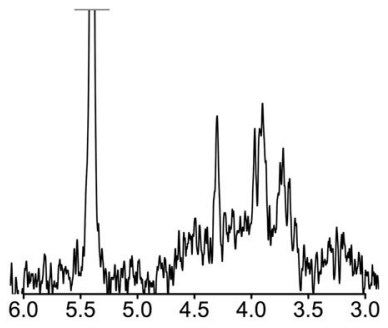

Year 20

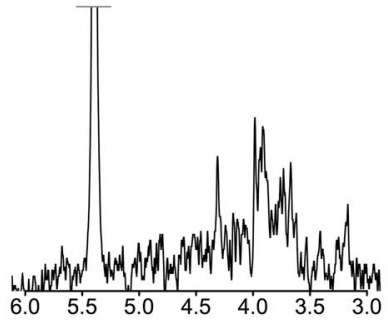

Year $26^{*}$

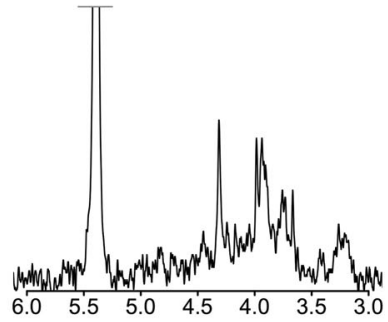

Native sites

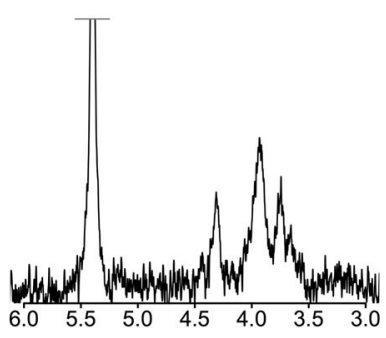

Fig. 3 The orthophosphate and phosphomonoester region ( $\delta 6$ to $3 \mathrm{ppm}$ ) of solution ${ }^{31} \mathrm{P}$ NMR spectra on $\mathrm{NaOH}-\mathrm{EDTA}$ extracts of soils $(0-4 \mathrm{~cm})$ in relation to restoration period (years), and the native unburned (UB - black) and burned (AB - grey) at the Gove bauxite mine (sampled October 2002). The vertical scale of each spectrum has been independently magnified to highlight spectral features. Peaks were tentatively assigned to: orthophosphate $(\mathrm{A}=\delta 5.4 \mathrm{ppm})$, an unknown phosphomonoester $(\mathrm{B}=\delta$ $5.3 \mathrm{ppm}), \alpha$-glycerophosphate $(\mathrm{C}=\delta 4.4 \mathrm{ppm})$, an unknown phosphomonoester with a somewhat broad signal at Site UB but

across all restoration periods were much higher than at both native forest sites.

Classes of $\mathrm{P}$ detected in solution ${ }^{31} \mathrm{P}$ NMR spectra of all $\mathrm{NaOH}-\mathrm{EDTA}$ extracts were those of orthophosphate, phosphomonoesters, phosphodiesters, and pyrophosphate. The majority of the NMR signal occurred in the orthophosphate and phosphomonoester region $(\delta 5.6$ to $2.8 \mathrm{ppm}$ ), which has been magnified in Fig. 3. In general, all spectra exhibited a low signal-to-noise ratio. However, several sharp and broad signals could be observed in the phosphomonoester region. Peaks were assigned to an unknown phosphomonoester with a sharp signal $(\mathrm{B}=\delta 5.3 \mathrm{ppm})$ adjacent to the orthophosphate peak, $\alpha$-glycerophosphate $(\mathrm{C}=\delta 4.4 \mathrm{ppm})$, an unknown phosphomonoester(s) with a somewhat broad signal $(\mathrm{D}=$ spanning $\delta 4.1$ to 3.9$)$, some RNA mononucleotides $(\delta 3.81,3.74$ and $3.68 \mathrm{ppm})$, an unknown phosphomonoester with a sharp signal ( $\delta 3.5 \mathrm{ppm})$, and broad phosphomonoesters $(\mathrm{F}=$ spanning $\delta 4.8$ to $3.4 \mathrm{ppm})$.

The chemical nature of phosphomonoesters at site UB was different to that at site $\mathrm{AB}$, but similar to the soils along the 26-year chronosequence (Fig. 3). The chemical nature of phosphomonoesters within the 26year chronosequence was generally the same, except that at the beginning (site year 2), which had less signal.

The concentration of organic $\mathrm{P}$ (phosphomonoesters and phosphodiesters) in NaOH-EDTA extracts as determined by NMR spectroscopy was $7.2 \mathrm{mg} \mathrm{kg}^{-1}$ at year 2 (Table 4). The concentration of organic $\mathrm{P}$ increased along the 26-year chronosequence but remained relatively constant with an average of $15 \mathrm{mg} \mathrm{kg}^{-1}$, which was similar to site UB (Table 3). Phosphomonoesters were the dominant class of organic $\mathrm{P}$ across all soils, which were on average $82 \%$ of the organic P. In general, concentrations 
Table 4 Concentrations $\left(\mathrm{mg} \mathrm{kg}^{-1}\right)$ of $\mathrm{P}$ classes in NaOH-EDTA extracts (1:4 soil to solution ratio) of soils $(0-4 \mathrm{~cm})$ along the chronosequence of restored sites, a long unburned native forest site (UB), and an unmined, previously burned native forest site (AB) (sampled October 2002)

\begin{tabular}{lllll}
\hline Restoration period (years) & Mono-P & Di-P & Pyro-P & Organic P \\
\hline 2 & 5.7 & 1.5 & 2.7 & 7.2 \\
4 & 12.5 & 2.4 & 4.4 & 14.9 \\
8 & 10.4 & 1.5 & 5.2 & 11.8 \\
13 & 12.9 & 0.9 & 5.4 & 13.8 \\
17 & 13.5 & 1.4 & 1.5 & 14.9 \\
20 & 14.4 & 3.2 & 1.3 & 17.6 \\
26 & 12.0 & 2.7 & 0.0 & 14.7 \\
Native forest sites & & & & \\
$\quad$ UB & 12.9 & 3.5 & 1.0 & 16.4 \\
\multicolumn{1}{c}{ AB } & 4.1 & 2.3 & 2.2 & 6.4 \\
\hline
\end{tabular}

Orthophosphate was not included because it was not determined quantitatively using NMR spectroscopy. Organic P refers to the total concentration of phosphomonoesters and phosphodiesters

of pyrophosphate were low $\left(<5.4 \mathrm{mg} \mathrm{kg}^{-1}\right)$ but noticeably higher than those of phosphodiesters up to 13 years of restoration.

\section{Discussion}

We hypothesised that the initial phase of successful soil and ecosystem development requires the formation of a developing pool of organically associated P. Several lines of evidence indicate that this is likely to have been achieved, perhaps initiated through the initial fertilizer $\mathrm{P}$ subsidy. These include increases in the concentrations of $\mathrm{Pt}$ and in the shorter-term-available P fractions together with their strong associations with the increasing organic matter concentrations. Additionally, the reestablishment of biogeochemical $\mathrm{P}$ cycling is evidenced in the properties of the organic $\mathrm{P}$ pools, while aboveground evidence is related to the satisfactory growth and development of the plant community at these sites.

\section{Total phosphorus}

Total $\mathrm{P}$ concentrations in the $<2 \mathrm{~mm}$ fraction of the unmined local surface forest soils studied here are commensurate with the low values reported for oxisols elsewhere (Negassa and Leinweber 2009; Yang and Post 2011; Kooyman et al. 2017; Viscarra Rossel and Bui 2016). Mean Pt in the $0-10 \mathrm{~cm}$ interval of the restored soils was estimated to be $316 \mathrm{mg} \mathrm{kg}^{-1}$, some $14 \%$. higher than in local native forest soils; below $10 \mathrm{~cm}$ depth and in the mine floor concentrations were of similar magnitude to those of the native forest site $\mathrm{AB}$. In contrast to the findings of a similar study conducted elsewhere in tropical Australia (Short et al. 2000), Pt was positively correlated with restoration period indicating the potential to accumulate $\mathrm{P}$ in the upper profile (Deng et al. 2017; Shi et al. 2016).

Phosphorus fractionation

The present $\mathrm{P}$ fractionation studies have indicated that significant increases with restoration period occurred in Labile $P$ and Long-term $P$ concentrations in the nearsurface soils over the 26-year chronosequence of restored sites; it also seems likely that Intermediate-term $P$ and Biological $P$ will increase in concentration over longer restoration periods. Clear declines in these four fractions occurred with increasing depth and values in the lower soils were little different to those of a local native forest soil. Soil Labile $P$ and Intermediate $P$ fractions were dominantly organic while Long-term $P$ was dominantly inorganic.

In the mine floor layer, the increases in Hydroxide $P_{i}$ and Conc. $\mathrm{HCl} P_{i}$ that occur with restoration period suggest possible accumulation following eluviation and perhaps leaching from the overlying soil materials or in preferential flow (see, for example, Lang et al. 2016; McGroddy et al. 2008). Such increases further suggest the possibility of continuing losses of inorganic and perhaps organic $\mathrm{P}$ to underlying strata in these highly permeable materials (see also Negassa and Leinweber 2009). Alternatively, some of these effects may also result from redistribution from other fractions, possibly Residual $P$.

Relationships between total phosphorus, the derived fractions and other soil properties

Concentrations of $\mathrm{Pt}$, Labile $P$, Intermediate $P$, Long-term $P$, Biological $P$ and Residual $P$ were all strongly positively correlated with those of total $\mathrm{C}$ 
and total $\mathrm{N}$ in the restored soils, illustrating their clear associations with soil organic matter status (see also Johnson et al. 2003; Dieter et al. 2010). These associations, together with the highly significant negative correlations between the clay content and the derived fractions, with $\mathrm{Pt}$ and with $\mathrm{C}$ and $\mathrm{N}$ concentrations may indicate a dilution effect. This could act through the occlusion of exchange sites by soil organic matter due to the strong associations among soil organic matter, phyllosilicate clays and the oxide minerals common in these soils (see, for example, Ye et al. 2017). The ratios of C/Biological $P$ varied little in relation to either depth or restoration period.

Chemical nature of soil organic phosphorus

In this study, concentrations of $\mathrm{NaOH}-\mathrm{EDTA}$ extractable organic $\mathrm{P}$ were extremely low (between 1.8 and $26 \mathrm{mg} \mathrm{kg}^{-1}$ ), and generally much lower than that typically reported in the literature for organic P characterisation using NMR spectroscopy (e.g., Doolette et al. 2011b; Stutter et al. 2012). McLaren et al. (2014) reported a NMR spectrum of a Vertisol soil taken from the $10-30 \mathrm{~cm}$ layer of a soil profile under cropping, which had a concentration of $18 \mathrm{mg} \mathrm{kg}^{-1}$ of $\mathrm{NaOH}-\mathrm{EDTA}$ extractable organic P. The NMR spectrum was dominated by a broad signal but the identification of sharp peaks within the phosphomonoester region was difficult. Similarly, Turner et al. (2003b) reported a NMR spectrum of a sandy soil taken from the $0-30 \mathrm{~cm}$ layer of a soil profile under cropping, which had a concentration of $21 \mathrm{mg} \mathrm{kg}^{-1}$ of $\mathrm{NaOH}-\mathrm{EDTA}$ extractable organic P. The NMR spectrum did not exhibit any identifiable peaks within the phosphomonoester region. In the current study, a narrow (1:4) soil to solution ratio was used to increase the concentration of organic $P$ in $\mathrm{NaOH}-\mathrm{EDTA}$ extracts (McLaren et al. 2015a) in order to provide some insight into the chemical nature of organic $\mathrm{P}$ along the 26-year chronosequence of these oxidic soils.

Solution ${ }^{31} \mathrm{P}$ NMR spectra of the NaOH-EDTA extracts revealed that phosphomonoesters were the dominant form of organic $\mathrm{P}$ in these soils, which is consistent with previous studies in tropical regions (Solomon and Lehmann 2000). Whilst the spectra did exhibit a low signal-to-noise ratio, several peaks could be observed within the phosphomonoester region. In particular, the alkaline hydrolysis products of phospholipids ( $\alpha$ - and $\beta$ - glycerophosphate: $\delta 4.4$ and $\sim 4.0 \mathrm{ppm}$ ) and RNA (RNA mononucleotides: $\delta 3.81,3.74$ and 3.68 ppm) (Doolette et al. 2009; Turner et al. 2003a), some unknown phosphomonoesters that exhibited a sharp signal $(\delta 5.3$ and $3.5 \mathrm{ppm}$ ), and some broad phosphomonoesters underneath the sharp signals (spanning $\delta 4.8$ to $3.4 \mathrm{ppm}$ ), which have been attributed to complex phosphomonoesters in high molecular weight material (McLaren et al. 2015b).

In general, the chemical nature of phosphomonoesters in these soils is somewhat different to that typically found in other soils. In particular, the overall dominance of a broad signal within the phosphomonoester region is not as evident in these soils compared to those in other Ferralsol soils under grassland and cropping (Doolette et al. 2011b; Jarosch et al. 2015) and there also appears to be a lack of inositol phosphates which have also been detected in Ferralsol soils (Doolette et al. 2011b; Jarosch et al. 2015). This might indicate a rapid turnover of added organic $\mathrm{P}$ by microorganisms and a low input of organic $\mathrm{P}$ from living organisms, particularly of plant seeds (Bünemann et al. 2008; Doolette et al. 2010).

The presence of alkaline hydrolysis products of phospholipids and RNA, phosphodiesters and pyrophosphate in these soils indicates the importance of microbial cycling of P (Condron et al. 2005). Concentrations of organic P in the 'labile' fraction were on average $30 \%$ of the combined pools of phosphomonoesters and phosphodiesters in $\mathrm{NaOH}-\mathrm{EDTA}$ extracts at similar soil depths across all sites (Table 4), which indicates their importance for biological cycling of P. Minimal changes in the concentration and chemical nature of soil organic $\mathrm{P}$ after Year 4 of the chronosequence, and a similar chemical composition of organic $P$ in these soils to that of the unburned native forest site (UB), suggest that the accumulation of organic $\mathrm{P}$ is relatively fast although it is then rapidly cycled by living organisms. If further accumulation of organic $\mathrm{P}$ is to occur, the addition of organic inputs and soluble forms of $\mathrm{P}$ is likely needed.

The previously burned native forest site $(\mathrm{AB}) \mathrm{had}$ the lowest concentration of organic $\mathrm{P}$, and its chemical nature was markedly different to that of all other sites. It is likely that high temperatures in the soil surface during burning have an adverse effect on soil organic matter (González-Pérez et al. 2004). Therefore, strategies aimed at sequestrating $\mathrm{P}$ in soil organic matter would need to account for losses via burning. 
Environmental significance

The overall temporal development of $\mathrm{P}$ status and of the various $\mathrm{P}$ fractions seems likely to be broadly defined by the successful and consistently applied restoration processes, extending also to the plant species sown and the initial fertilizer P subsidy (c. $25 \mathrm{~kg}$ $\mathrm{P} \mathrm{ha}^{-1}$ ) (Spain et al. 2015). This has led to the relatively rapid and even development of the plant community giving rise, in turn, to the ongoing net increases in near-surface concentrations of Pt, particularly the organic Labile P and long-term inorganic soil components, soil organic matter status and the other pedogenetic changes that have occurred with increasing restoration period.

Initially, $\mathrm{P}$ uptake is likely dominated by the sown grasses whose roots penetrate to depths below the soil profile within the first year after site restoration. The succession from grass to shrub and then to eucalypt dominance implies a change in the dominant $\mathrm{P}$ nutritional strategies during community development from arbuscular to mixed arbuscular and ectomycorrhizal fungal dominance. Following canopy closure, substantial litter layers develop, comprising a standing crop of $\mathrm{P}$ estimated at c. $8 \mathrm{~kg} \mathrm{ha}^{-1}$.

Microbial decomposition of litter and the turnover of fine roots have, together with bioturbation by termites, ants and earthworms (Spain et al. 2010; 2015), led to the formation of a pedoderm (Fey et al. 2006), a narrow organic-matter-enriched surface layer occurring at the interface with the substantial litter layers at sites restored for more than c. eight years; however, the effects of soil organic matter extend well below this layer. The higher near-surface values are also likely influenced by plant uptake and the reestablishment of biological recycling processes (Jobbágy and Jackson 2004; Nziguheba and Bünemann 2005; Dieter et al. 2010).

Phosphorus status also depends on the balance of acquisitions through fertilization and other inputs and the losses, redistributions and transformations that are associated with site vegetation clearing, soil mixing, organic matter decomposition and mineralisation, eluviation and leaching during soil handling and storage, mining and site restoration processes. Ongoing losses through eluviation and perhaps leaching will likely also continue post restoration, perhaps associated with the development of preferential flow pathways (Bol et al. 2016; Negassa and Leinweber 2009).
Such losses are to be expected during early ecosystem development (Odum 1985) and to decline with increasing maturity in these highly permeable and rapidly re-organising soils (Spain et al. 2015). As illustrated by the differences in organic $\mathrm{P}$ between burned and long-unburned native forest sites, the introduction of firing to the restored sites is likely to lead to profound changes in the amounts, lateral and vertical distributions and properties of organic materials and their associated organic P compounds.

At least one of the major dominant species (E. tetrodonta) is known to be $\mathrm{P}$ responsive in the presence of mycorrhizas (Jasper and Davy 1993). From a management perspective, the higher concentrations of particularly the Labile $P$ and Intermediate $P$ fractions in the longer-restored soils in comparison to those of the native forest reference site $\mathrm{AB}$ are likely to be considered satisfactory in terms of the growth of the two dominant overstorey Eucalyptus species. Nonetheless, it is also possible that even the moderate rate of fertilizer $P$ applied here may directly influence the level of understorey biodiversity through its effects on the recruitment and growth of P-sensitive plant species, or by promoting weed competition (see, for example, Daws et al. 2015; Prober and Wiehl 2012).

Acknowledgements We thank Dieter Hinz, former restoration supervisor, for his guidance during the sampling conducted for this work. The authors would also like to thank Dr. René Verel of the Laboratory of Inorganic Chemistry (Hönngerberg, ETH Zürich) and Dr. Laurie Paule Schönholzer of the Group of Plant Nutrition for technical assistance. We further thank Yvonne Siebert for her able technical contribution to this project. We also thank Dr. Glenn De'Ath (Australian Institute of Marine Science, Townsville) for the analysis of deviance presented in Table 1 and the fitted functions presented in Fig. 2. Anonymous referees assisted in improving earlier drafts of this manuscript. We acknowledge support from the Building Outstanding Impact Support Programme (H\&F38) from the University of Reading awarded to Mark Tibbett.

\section{Compliance with ethical standards}

Conflicts of interest Samples were collected during field work conducted by AVS and MT and are part of a wider contract of research with CSIRO under ISBN 978-1-74,052-170-3. AVS and MT designed the project and conducted the field work. MR supervised the $\mathrm{P}$ fractionation analyses and the $\mathrm{X}$-ray fluorescence analysis of the selected total elements. TM carried out the ${ }^{31} \mathrm{P}$ NMR analyses. The manuscript was written by AVS, MT, MR and TM. Some of the P fractionation data reported here have been previously published in summary form (Spain et al. 2006; 2009a, b; 2015). 


\section{Appendix}

Table 5 Selected properties of the soils of the chronosequence of restored sites and an unmined native forest site, AB (sampled May 2002)

\begin{tabular}{|c|c|c|c|c|c|c|}
\hline Years & Depth range $(\mathrm{cm})$ & $\mathrm{Pt}\left(\mathrm{mg} \mathrm{kg}^{-1}\right)$ & $\mathrm{C}\left(\mathrm{g} \mathrm{kg}^{-1}\right)$ & $\mathrm{N}\left(\mathrm{g} \mathrm{kg}^{-1}\right)$ & Clay (\% of $<2 \mathrm{~mm}$ fraction) & Silt ( $\%$ of $<2 \mathrm{~mm}$ fraction) \\
\hline 1 & $0-4$ & 223 & 11.60 & 0.42 & 26.3 & 17.6 \\
\hline 1 & $>4-8$ & 240 & 11.60 & 0.42 & 27.5 & 16.2 \\
\hline 1 & $50-60$ & 223 & 13.50 & 0.47 & 25.9 & 16.1 \\
\hline 1 & $70-80$ & 267 & 2.26 & 0.06 & 17.2 & 6.5 \\
\hline${ }^{\mathrm{a}} 2$ & $0-1.5$ & 280 & 16.00 & 0.58 & 28.3 & 12.2 \\
\hline $\mathrm{b}_{2}$ & $0-1.5$ & 328 & 44.00 & 1.67 & 25.8 & 12.1 \\
\hline 2 & $>1.5-4.0$ & 236 & 9.50 & 0.36 & 29.4 & 13.1 \\
\hline 2 & $60-70$ & 227 & 9.80 & 0.40 & 29.6 & 14.2 \\
\hline 2 & $100-110$ & 240 & 11.00 & 0.42 & 28.4 & 14.5 \\
\hline 4 & $0-4$ & 227 & 16.40 & 0.77 & 33.9 & 18.7 \\
\hline 4 & $5-10$ & 210 & 15.20 & 0.67 & 31.8 & 19.5 \\
\hline 4 & $20-25$ & 144 & 2.52 & 0.14 & 48.2 & 13.3 \\
\hline 4 & $50-60$ & 140 & 3.40 & 0.19 & 46.1 & 12.9 \\
\hline 4 & $90-100$ & 192 & 4.76 & 0.20 & 33.9 & 11.3 \\
\hline 8 & $0-4$ & 227 & 16.20 & 0.67 & 36.9 & 9.9 \\
\hline 8 & $>4-8$ & 232 & 10.20 & 0.44 & 39.4 & 10.6 \\
\hline 8 & $50-60$ & 223 & 7.38 & 0.32 & 39.0 & 9.7 \\
\hline 8 & 95-105 & 170 & 2.00 & 0.05 & 24.6 & 5.7 \\
\hline 13 & $1.5-3.0$ & 315 & 26.40 & 1.03 & 26.8 & 15.8 \\
\hline 13 & $>3-7$ & 315 & 15.70 & 0.70 & 31.6 & 14.0 \\
\hline 13 & $40-50$ & 232 & 9.27 & 0.34 & 29.4 & 12.9 \\
\hline 13 & $75-85$ & 197 & 1.86 & 0.05 & 16.1 & 5.7 \\
\hline 20 & $0-4$ & 262 & 44.30 & 1.64 & 26.0 & 18.0 \\
\hline 20 & $>4-9$ & 271 & 14.50 & 0.70 & 35.0 & 14.2 \\
\hline 20 & $40-50$ & 214 & 7.63 & 0.32 & 27.1 & 10.6 \\
\hline 20 & $60-70$ & 192 & 2.22 & 0.07 & 20.4 & 6.8 \\
\hline 26 & $0-1.5$ & 350 & 114.00 & 5.01 & 14.1 & 20.2 \\
\hline 26 & $>1.5-5.5$ & 315 & 31.70 & 1.72 & 28.1 & 19.0 \\
\hline 26 & $12-17$ & 210 & 12.50 & 0.50 & 26.2 & 18.2 \\
\hline 26 & $60-70$ & 210 & 9.23 & 0.39 & 28.6 & 17.1 \\
\hline 26 & $105-115$ & 214 & 2.13 & 0.07 & 17.0 & 6.2 \\
\hline${ }^{\mathrm{c}} \mathrm{N}$ & $0-2.5$ & 219 & 32.50 & 0.93 & 13.2 & 20.4 \\
\hline $\mathrm{N}$ & $>2.5-7.5$ & 170 & 12.20 & 0.53 & 21.9 & 17.8 \\
\hline $\mathrm{N}$ & $7.5-12$ & 175 & 8.30 & 0.41 & 21.2 & 19.9 \\
\hline $\mathrm{N}$ & $60-70$ & 197 & 5.31 & 0.31 & 31.6 & 17.6 \\
\hline $\mathrm{N}$ & $75-85$ & 179 & 2.86 & 0.11 & 31.2 & 5.9 \\
\hline
\end{tabular}

${ }^{a}$ Ridge top sample

${ }^{\mathrm{b}}$ Furrow sample

${ }^{\mathrm{c}}$ Native forest site $\mathrm{AB}$, with medium profile depth 
Table 6 Concentrations of the chemically defined $\mathrm{P}$ fractions $\left(\mathrm{mg} \mathrm{kg}^{-1}\right)$ in the soils of the chronosequence of restored sites and in an unmined native forest, $\mathrm{AB}$ (<dl, less than detection limit) (sampled May 2002)

\begin{tabular}{|c|c|c|c|c|c|c|c|c|c|}
\hline $\begin{array}{l}\text { Age } \\
\text { (y) }\end{array}$ & $\begin{array}{l}\text { Depth range } \\
(\mathrm{cm})\end{array}$ & $\begin{array}{l}\text { Resin } \\
\text { P }\end{array}$ & $\begin{array}{l}\text { Bicarbonate } \\
\mathrm{P}_{\mathrm{i}}\end{array}$ & $\begin{array}{l}\text { Bicarbonate } \\
\mathrm{P}_{\mathrm{o}}\end{array}$ & $\begin{array}{l}\mathrm{NaOH} \\
\mathrm{P}_{\mathrm{i}}\end{array}$ & $\begin{array}{l}\mathrm{NaOH} \\
\mathrm{P}_{\mathrm{o}}\end{array}$ & $\begin{array}{l}\text { Dilute HCI-extr. } \\
\mathrm{P}_{\mathrm{i}}\end{array}$ & $\begin{array}{l}\text { Conc. HCl-extr } \\
\mathrm{P}_{\mathrm{i}}\end{array}$ & $\begin{array}{l}\text { Conc. HCl-extr } \\
\mathrm{P}_{\mathrm{o}}\end{array}$ \\
\hline 1 & $0-4$ & 0.4 & $<\mathrm{dl}$ & 0.1 & 1.7 & 31.6 & 8.0 & 40.7 & 0.2 \\
\hline 1 & $>4-8$ & 0.1 & $<\mathrm{dl}$ & $<\mathrm{dl}$ & 1.2 & 35.8 & 1.7 & 42.7 & $<\mathrm{dl}$ \\
\hline 1 & $50-60$ & 0.3 & $<\mathrm{dl}$ & 0.7 & 1.7 & 15.7 & 2.0 & 45.1 & $<\mathrm{dl}$ \\
\hline 1 & $70-80$ & 0.2 & 0.4 & $<\mathrm{dl}$ & 20.2 & 10.0 & 0.5 & 21.5 & $<\mathrm{dl}$ \\
\hline${ }^{a} 2$ & $0-1.5$ & 1.3 & $<\mathrm{dl}$ & 6.8 & 7.8 & 14.1 & 2.1 & 58.4 & $<\mathrm{dl}$ \\
\hline $\mathrm{b}_{2}$ & $0-1.5$ & 4.8 & 1.5 & 2.8 & 14.6 & 42.6 & 2.2 & 61.3 & $<\mathrm{dl}$ \\
\hline 2 & $1.5-4.0$ & $<\mathrm{dl}$ & $<\mathrm{dl}$ & 1.2 & 4.7 & 15.0 & 1.7 & 50.2 & $<\mathrm{dl}$ \\
\hline 2 & $60-70$ & $<\mathrm{dl}$ & $<\mathrm{dl}$ & 1.4 & 2.1 & 25.9 & 1.0 & 41.3 & $<\mathrm{dl}$ \\
\hline 2 & $100-110$ & $<\mathrm{dl}$ & $<\mathrm{dl}$ & 1.0 & 4.6 & 26.3 & 2.2 & 32.0 & 4.7 \\
\hline 4 & $0-4$ & 1.1 & 0.7 & 5.0 & 4.2 & 47.2 & 1.9 & 31.0 & $<\mathrm{dl}$ \\
\hline 4 & $5-10$ & 1.0 & $<\mathrm{dl}$ & 1.2 & 3.2 & 21.8 & 1.1 & 24.4 & $<\mathrm{dl}$ \\
\hline 4 & $20-25$ & 0.1 & $<\mathrm{dl}$ & $<\mathrm{dl}$ & 3.2 & $<\mathrm{dl}$ & 1.7 & 12.5 & $<\mathrm{dl}$ \\
\hline 4 & $50-60$ & $<\mathrm{dl}$ & $<\mathrm{dl}$ & $<\mathrm{dl}$ & 3.5 & 1.0 & 1.6 & 14.8 & $<\mathrm{dl}$ \\
\hline 4 & $90-100$ & 0.2 & $<\mathrm{dl}$ & $<\mathrm{dl}$ & 1.7 & 6.2 & 1.3 & 27.6 & $<\mathrm{dl}$ \\
\hline 8 & $0-4$ & 0.8 & 0.2 & 1.6 & 6.8 & 29.9 & 1.3 & 34.2 & 5.2 \\
\hline 8 & $>4-8$ & 0.3 & 0.1 & 1.7 & 6.0 & 25.8 & 5.5 & 39.0 & $<\mathrm{dl}$ \\
\hline 8 & $50-60$ & 0.5 & $<\mathrm{dl}$ & 2.1 & 0.9 & 9.7 & 1.1 & 29.4 & 0.7 \\
\hline 8 & $95-105$ & 0.3 & $<\mathrm{dl}$ & $<\mathrm{dl}$ & 9.1 & 7.5 & 1.4 & 14.6 & $<\mathrm{dl}$ \\
\hline 13 & $1.5-3.0$ & 2.4 & $<\mathrm{dl}$ & 5.5 & 9.6 & 34.9 & 1.1 & 70.5 & $<\mathrm{dl}$ \\
\hline 13 & $>3-7$ & 1.2 & 0.7 & 4.6 & 7.5 & 44.5 & 0.9 & 65.6 & $<\mathrm{dl}$ \\
\hline 13 & $40-50$ & 0.3 & $<\mathrm{dl}$ & $<\mathrm{dl}$ & 1.5 & 25.8 & 1.3 & 57.7 & 1.4 \\
\hline 13 & $75-85$ & 0.2 & 1.0 & $<\mathrm{dl}$ & 10.6 & 0.8 & 1.2 & 31.1 & $<\mathrm{dl}$ \\
\hline 20 & $0-4$ & 6.0 & $<\mathrm{dl}$ & 3.3 & 7.2 & 13.7 & 1.3 & 60.6 & $<\mathrm{dl}$ \\
\hline 20 & $>4-9$ & 0.9 & $<\mathrm{dl}$ & 2.8 & 2.2 & 20.0 & 0.6 & 82.9 & $<\mathrm{dl}$ \\
\hline 20 & $40-50$ & 0.1 & $<\mathrm{dl}$ & 1.3 & 1.8 & 13.5 & 1.1 & 41.2 & $<\mathrm{dl}$ \\
\hline 20 & $60-70$ & 0.3 & 0.7 & $<\mathrm{dl}$ & 13.0 & 5.2 & 1.34 & 33.1 & $<\mathrm{dl}$ \\
\hline 26 & $0-1.5$ & 18.9 & $<\mathrm{dl}$ & 8.7 & 5.9 & 50.1 & 3.8 & 61.5 & 10.8 \\
\hline 26 & $>1.5-5.5$ & 3.2 & $<\mathrm{dl}$ & 5.0 & 9.5 & 44.7 & 2.4 & 60.7 & 4.3 \\
\hline 26 & $12-17$ & $<\mathrm{dl}$ & $<\mathrm{dl}$ & 1.5 & 6.0 & 21.6 & 2.7 & 38.7 & $<\mathrm{dl}$ \\
\hline 26 & $60-70$ & $<\mathrm{dl}$ & $<\mathrm{dl}$ & 1.5 & 3.7 & 23.8 & 1.5 & 51.7 & $<\mathrm{dl}$ \\
\hline 26 & $105-115$ & $<\mathrm{dl}$ & 0.2 & 1.3 & 17.5 & $<\mathrm{dl}$ & 1.3 & 48.1 & 0.9 \\
\hline${ }^{\mathrm{c}} \mathrm{N}$ & $0-2.5$ & 1.3 & $<\mathrm{dl}$ & 1.8 & 14.6 & 20.3 & 2.7 & 28.8 & 8.7 \\
\hline $\mathrm{N}$ & $>2.5-7.5$ & $<\mathrm{dl}$ & $<\mathrm{dl}$ & 1.2 & 3.5 & 18.7 & 3.4 & 18.3 & 12.5 \\
\hline $\mathrm{N}$ & $7.5-12$ & $<\mathrm{dl}$ & $<\mathrm{dl}$ & 0.6 & 2.5 & 21.8 & 2.3 & 27.7 & $<\mathrm{dl}$ \\
\hline $\mathrm{N}$ & $60-70$ & $<\mathrm{dl}$ & $<\mathrm{dl}$ & 0.7 & 3.1 & 5.1 & 2.5 & 26.0 & $<\mathrm{dl}$ \\
\hline $\mathrm{N}$ & $75-85$ & $<\mathrm{dl}$ & $<\mathrm{dl}$ & $<\mathrm{dl}$ & 9.5 & $<\mathrm{dl}$ & 3.2 & 23.9 & 3.0 \\
\hline
\end{tabular}

${ }^{\text {a }}$ Ridge top sample

${ }^{\mathrm{b}}$ Furrow sample

${ }^{\mathrm{c}}$ Native forest site $\mathrm{AB}$, with medium profile depth 
Open Access This article is distributed under the terms of the Creative Commons Attribution 4.0 International License (http:// creativecommons.org/licenses/by/4.0/), which permits unrestricted use, distribution, and reproduction in any medium, provided you give appropriate credit to the original author(s) and the source, provide a link to the Creative Commons license, and indicate if changes were made.

\section{References}

Bol R, Julich D, Brődlin D, Siemens J, Kaiser K, Dippold MA, Spielvogel S, Zilla T, Mewes D, von Blanckenburg F, Pulhmann H, Holzmann S, Weiler M, Amelung W, Lang F, Kuzyakov Y, Feger K-H, Gottselig N, Klumpp E, Missong A, Winkelmann C, Uhlig D, Sohrt J, von Wilpert K, Wu B, Hagedorn F (2016) Dissolved and colloidal phosphorus fluxes in forest ecosystems - an almost blind spot in ecosystem research. J Plant Nutr Soil Sci 179:425-438

Bünemann EK, Smernik RJ, Marschner P, McNeill AM (2008) Microbial synthesis of organic and condensed forms of phosphorus in acid and calcareous soils. Soil Biol Biochem 40(4): 932-946

Bureau of Meteorology Australia (2015) Summary statistics Gove A i r p o r t, ht t p:// w w w b o m.g o v. au/climate/averages/tables/cw_014508.shtml (consulted 30 November 2015)

Cade-Menun BJ, Liu CW (2014) Solution phosphorus-31 nuclear magnetic resonance spectroscopy of soils from 2005 to 2013: a review of sample preparation and experimental parameters. Soil Sci Soc Am J 78(1):19-37

Cade-Menun BJ, Preston CM (1996) A comparison of soil extraction procedures for ${ }^{31} \mathrm{P}$ NMR spectroscopy. Soil Sci 161(11): 770-785

Cleveland CC, Townsend AR, Taylor P, Alvarez-Clare S, Bustamente MMC, Chuyong G, Dobrowski SZ, Grierson P, Harms KE, Houlton BZ, Marklein A, Parton W, Porder S, Reed SC, Sierra CA, Silver WL, Tanner EVJ, Wiede WR (2011) Relationships among net primary productivity, nutrients and climate in tropical rain forest: a pan-tropical analysis. Ecol Lett 14:939-947

Condron LM, Newman S (2011) Revisiting the fundamentals of phosphorus fractionation of sediments and soils. J Soils Sediments 11:830-840

Condron LM, Turner BL, Cade-Menun BJ (2005). Chemistry and dynamics of soil organic phosphorus. In JT Sims and AN Sharpley (ed) Phosphorus: agriculture and the environment. Madison, ASA CSSA SSSA, 46, Wisconsin USA

Cook GD (2012) Fire management and minesite rehabilitation in a frequently burnt tropical savanna. Austral Ecol 37:686-692

Cornell RM, Schwertmann U (2003) The iron oxides - structure, properties, reactions, occurrences and uses, 2nd edn. WileyVCH, Weinheim

Crews TE, Kitayama K, Fownes JH, Riley RH, Herbert DA, Mueller-Dombois D, Vitousek PM (1995) Changes in soil phosphorus fractions and ecosystem dynamics across a long chronosequence in Hawaii. Ecology 76:1407-1424
Cross AF, Schlesinger WH (1995) A literature review and evaluation of the Hedley fractionation: applications to the biogeochemical cycle of soil phosphorus in natural ecosystems. Geoderma 64:197-214

Daws MI, Standish RJ, Koch JM, Morald TK, Tibbett M, Hobbs RJ (2015) Phosphorus fertilisation and large legume species affect jarrah forest restoration after bauxite mining. For Ecol Manag 354:10-17

Deng Q, McMahon DE, Xiang Y, Yu Y, Jackson RL, Hui D (2017) A global meta-analysis of soil phosphorus dynamics after afforestation. New Phytol 213:181-192

Department of Sustainability, Environment, Water, Population and Communities (2008) Rangelands - taking the pulse, Arnhem coast bioregion, <http://www.environment.gov. $\mathrm{au} /$ land/publications/acris/pubs/bioregionarnhem-coast.pdf>

Department of the Environment, Great Britain (1993) Phosphorus and silicon in wastes, effluents and sludges - 1992, revised edition, Her Majesty's Stationary Office, Norwich, United Kingdom

Dieter D, Elsenbeer H, Turner BL (2010) Phosphorus fractionation in lowland tropical rainforest soils in Central Panama. Catena 82:118-125

Doolette AL, Smernik RJ, Dougherty WJ (2009) Spiking improved solution phosphorus-31 nuclear magnetic resonance identification of soil phosphorus compounds. Soil Sci Soc Am J 73(3):919-927

Doolette AL, Smernik RJ, Dougherty WJ (2010) Rapid decomposition of phytate applied to a calcareous soil demonstrated by a solution ${ }^{31} \mathrm{P}$ NMR study. Eur J Soil Sci 61(4):563-575

Doolette AL, Smernik RJ, Dougherty WJ (2011a) Overestimation of the importance of phytate in $\mathrm{NaOH}-\mathrm{EDTA}$ soil extracts as assessed by ${ }^{31} \mathrm{P}$ NMR analyses. Org Geochem 42(8):955964

Doolette AL, Smernik RJ, Dougherty WJ (2011b) A quantitative assessment of phosphorus forms in some Australian soils. Soil Res 49(2): 152-165

Elser JJ, Bracken MES, Cleland EE, Gruner DS, Harpole WS, Hillebrand H, Ngai JT, Seabloom EW, Shurin JB, Smith JE (2007) Global analysis of nitrogen and phosphorus limitation of primary producers in freshwater, marine and terrestrial ecosystems. Ecol Lett 10:1135-1142

Fey MV, Mills AJ, Yaalon DH (2006) The alternative meaning of pedoderm and its use for soil surface characterization. Geoderma 133(3/4):474-477

Frossard E, Stewart JWB, St Arnaud RJ (1989) Distribution and mobility of phosphorus in grassland and forest soils of Saskatchewan. Can J Soil Sci 69:401-416

González-Pérez JA, González-Vila FJ, Almendros G, Knicker H (2004) The effect of fire on soil organic matter - a review. Environ Intl 30(6):855-870

Güsewell S (2004) N: P ratios in terrestrial plants: variation and functional significance. New Phytol 164:243-266

Isbell RF (1996) The Australian soil classification. CSIRO Publishing, Collingwood

IUSS Working Group WRB (2015) World reference base for soil resources 2014, update 2015, international soil classification system for naming soils and creating legends for soil maps. World soil resources reports no. 106, FAO, Rome

Jarosch KA, Doolette AL, Smernik RJ, Tamburini F, Frossard E, Bünemann EK (2015) Characterisation of soil organic phosphorus in NaOH-EDTA extracts: a comparison of ${ }^{31} \mathrm{P}$ NMR 
spectroscopy and enzyme addition assays. Soil Biol Biochem 91:298-309

Jasper DA, Davy JA (1993) Root characteristics of native plant species in relation to the benefit of mycorrhizal colonization for phosphorus uptake. Plant Soil 155-156:281-284

Jobbágy EG, Jackson RL (2004) The uplift of soil nutrients by plants: biogeochemical consequences across scales. Ecology 85:2380-2389

Johnson AH, Frizano J, Vann DR (2003) Biogeochemical implications of labile phosphorus in forest soils determined by the Hedley fractionation procedure. Oecologia 135:487-499

Knecht MF, Göransson A (2004) Terrestrial plants require nutrients in similar proportions. Tree Physiol 24:447-460

Kooyman R, Laffan SW, Westoby M (2017) The incidence of low phosphorus soils in Australia. Plant Soil 412:143-150

Lang F, Bauhus J, Frossard E, Eckhard G, Kaiser K, Kaupenjohann M, Krüger J, Matzner E, Polle E, Prietzel J, Rennenberg H (2016) Phosphorus in forest ecosystems: new insights from an ecosystem nutrition perspective. J Plant Nutr Soil Sci 179:129-135

McDowell RW, Stewart I, Cade-Menun BJ (2006) An examination of spin-lattice relaxation times for analysis of soil and manure extracts by liquid state phosphorus-31 nuclear magnetic resonance spectroscopy. J Environ Qual 35(1):293-302

McGroddy ME, Silver WL, de Oliveira RC Jr, de Mello WZ, Keller M (2008) Retention of phosphorus in highly weathered soils under a lowland Amazonian forest ecosystem. Journal of Geophysical Research, 113, G04012, 11pp

McLaren TI, Smernik RJ, Guppy CN, Bell MJ, Tighe MK (2014) The organic P composition of Vertisols as determined by ${ }^{31} \mathrm{P}$ NMR spectroscopy. Soil Sci Soc Am Journal 78(6):1893-1902

McLaren TI, Smernik RJ, Simpson RJ, McLaughlin MJ, McBeath TM, Guppy CN, Richardson AE (2015a) Spectral sensitivity of solution ${ }^{31} \mathrm{P}$ NMR spectroscopy is improved by narrowing the soil to solution ratio to $1: 4$ for pasture soils of low organic P content. Geoderma 257-258:48-57

McLaren TI, Smernik RJ, McLaughlin MJ, McBeath TM, Kirby JK, Simpson RJ, Guppy CN, Doolette AL, Richardson AE (2015b) Complex forms of soil organic phosphorus - a major component of soil phosphorus. Environ Sci Technol 49(22): 13238-13245

Negassa W, Leinweber P (2009) How does the Hedley sequential phosphorus fractionation reflect impacts of land use and management on soil phosphorus: a review. J Plant Nutr Soil Sci 172:305-325

Nziguheba G, Bünemann EK (2005) Organic phosphorus in tropical agroecosystems. In: Turner BL, Frossard E, Baldwin DS (eds) Organic phosphorus in the environment. CABI publishing, Wallingford, pp 243-269

O'Keefe D (1992) Bauxite mining and Walyamirri, the return of the living environment, paper one, the mining operation. Australian Mining Industry Council, Seventeenth Annual Environmental Workshop, Yeppoon, Queensland, 5-9 October, 1992, pp 88-99

Odum EP (1985) Trends expected in stressed ecosystems. Bioscience 35:419-422

Ohno T, Zibilske LM (1991) Determination of low concentrations of phosphorus in soil extracts using malachite green. Soil Sci Soc Am J 55(3):892-895
Peltzer DA, Wardle DA, Allison VJ, Baisden WT, Bardgett RD, Chadwick OA, Condron LM, Parfitt RL, Porder S, Richardson SJ, Turner BL, Vitousek PM, Walker J, Walker LR (2010) Understanding ecosystem retrogression. Ecol Monogr 80:509-529

Prober SM, Wiehl G (2012) Relationships among soil fertility, native plant diversity and exotic plant abundance inform restoration of forb-rich eucalypt woodlands. Divers Distrib 18:795-807

R Core Team (2016). R: a language and environment for statistical computing. R Foundation for Statistical Computing, Vienna, Austria. URL https://www.R-project.org/

Reddell P, Milnes AR (1992) Mycorrhizas and other specialised nutrient-acquisition strategies: their occurrence in woodland plants from Kakadu and their role in rehabilitation of waste rock dumps at a local uranium mine. Aust J Bot 40:223-242

Reed SC, Townsend AR, Taylor PG, Cleveland CC (2011) Phosphorus cycling in tropical forests growing on highly weathered soils. In: Bünneman ED, Oberson A, Frossard E (eds) Phosphorus in action. Springer, Heidelberg, pp 339-369

Reisser M, Purves RS, Schmidt MWI, Abiven S (2016) Pyrogenic carbon in soils: a literature-based inventory and a global estimation of its content in soil organic carbon and stocks. Front. Earth Sci 4:article 80

Shi S, Peng C, Wang M, Zhuz Q, Yang G, Yang Y, Xi T, Zhang T (2016) A global meta-analysis of changes in soil carbon, nitrogen, phosphorus and Sulphur, and stoichiometric shifts after forestation. Plant Soil 407:323-340

Short TA, Menzies NW, Mulligan DR (2000) Mining disturbance alters phosphorus fractions in northern Australian soils. Aust J Soil Res 38:411-421

Short TA, Kopittke PM, Mulligan DR, Menzies NW (2007) Growth of Eucalyptus species in a brown kandosol, and changes in soil phosphorus fractionation following fertilisation. Aust J Soil Res 45:190-198

Soil Survey Staff (1999) Soil taxonomy, a basic system of soil classification for making and interpreting soil surveys. United States Department of Agriculture, natural resource conservation service, Agriculture handbook 436, U.S. Government Printing Office, Washington, DC 20402

Solomon D, Lehmann J (2000) Loss of phosphorus from soil in semi-arid northern Tanzania as a result of cropping: evidence from sequential extraction and ${ }^{31} \mathrm{P}-\mathrm{NMR}$ spectroscopy. Eur J Soil Sci 51(4):699-708

Spain AV, Hinz DA, Ludwig J, Tibbett M (2006) Mine closure and ecosystem development: Alcan Gove bauxite mine, NT, Australia. In: Fourie A, Tibbett M (eds) Mine closure 2006, proceedings of the first international seminar on mine closure, $13-15^{\text {th }}$ September 2006. Australian Centre for Geomechanics, Perth, Australia, pp 299-308

Spain AV, Ludwig J, Tibbett M, Tongway D (2009a) Ecological and minesoil development studies at the Rio Tinto Alcan Gove mine site, Gove, NT, final report, Volume one - text. Centre for Land Rehabilitation, University of Western Australia, Perth, 455pp. (ISBN: 978174052170 3)

Spain AV, Ludwig J, Tibbett M, Tongway D (2009b) Ecological and minesoil development studies at the Rio Tinto Alcan Gove mine site, Gove, NT, final report, Volume Two Appendix Tables. Centre for Land Rehabilitation, 
University of Western Australia, Perth, 168pp. (ISBN: 9781 740521703 )

Spain AV, Hinz DA, Tibbett M (2010) Colonisation of rehabilitated lands by termites (Dictyoptera), Rio Tinto Australia Gove bauxite mine, NT, Australia. In: Fourie A, Tibbett M, Wiertz J (eds) Mine closure 2010, proceedings of the fifth international seminar on mine closure, 23-26 ${ }^{\text {th }}$ November, 2010, Viña del mar. Australian Centre for Geomechanics, Perth, Australia, pp 437-448

Spain AV, Tibbett M, Hinz DA, Ludwig JA, Tongway DJ (2015) The mining-restoration system and ecosystem development following bauxite mining in a biodiverse environment of the seasonally dry tropics, northern territory, Australia. In: Tibbett M (ed) Mining in environmentally sensitive landscapes. CSIRO publishing, Melbourne, pp 159-227

Stutter MI, Shand CA, George TS, Blackwell MSA, Bol R, MacKay RL, Richardson AE, Condron LM, Turner BL, Haygarth PM (2012) Recovering phosphorus from soil: a root solution? Environ Sci Technol 46(4):1977-1978

Taylor JK (1987) Quality assurance of chemical measurements. CRC Press, Boca Raton, Florida

Tiessen H, Moir JO (1993) Characterization of available P by sequential extraction. In: Carter $M$ (ed) Soil sampling and methods of analysis. Lewis Publishers, Boca Raton, Florida, pp 75-86

Tipping E, Benham S, Boyle JF, Crow P, Davies J, Fischer U, Guyatt H, Helliwell H, Jackson-Blake L, Lawlor AJ, Monteith DT, Rowe EC, Toberman H (2014) Atmospheric deposition of phosphorus to land and freshwater. Environ Sci: Processes Impacts 16:1608-1617
Turner BL, Mahieu N, Condron LM (2003a) Phosphorus-31 nuclear magnetic resonance spectral assignments of phosphorus compounds in soil NaOH-EDTA extracts. Soil Sci Soc Am J 67(2):497-510

Turner BL, Cade-Menun BJ, Westermann DT (2003b) Organic phosphorus composition and potential bioavailability in semi-arid arable soils of the western United States. Soil Sci Soc Am J 67(4):1168-1179

Vincent AG, Vestergren J, Gröbner JG, Persson P, Schleucher J, Giesler R (2013) Soil organic phosphorus transformations in a boreal forest chronosequence. Plant Soil 367(1-2):149-162

Viscarra Rossel RA, Bui EN (2016) A new detailed map of total phosphorus stocks in Australian soil. Sci Total Environ 542: 1040-1049

Vitousek PM (1984) Litterfall, nutrient cycling, and nutrient limitation in tropical forests. Ecology 65(1):285-298

Vitousek PM, Porder S, Houlton BZ, Chadwick OA (2010) Terrestrial phosphorus limitation: mechanisms, implications, and nitrogen-phosphorus interactions. Ecol Appl 20:5-15

Walker TW, Syers JK (1975) The fate of phosphorus during pedogenesis. Geoderma 15:1-19

Yang X, Post WM (2011) Phosphorus transformations as a function of pedogenesis: a synthesis of soil phosphorus data using Hedley fractionation method. Biogeosciences 8:2907-2916

Yang X, Post WM, Thornton PE, Jain A (2013) The distribution of soil phosphorus for global biogeochemical modelling. Biogeosciences 10:2525-2537

Ye C, Bai T, Yang Y, Zhang H, Guo H, Li Z, Li H (2017) Physical access for residue-mineral interactions controls organic carbon retention in an Oxisol soil. Sci Rep 7:6317 